\title{
Ocorrência de Phytophthora nicotianae em Lilium speciosum no Brasil
}

\author{
Marlon Vagner Valentim Martins ${ }^{1}$, Francisco das Chagas de Oliveira Freire ${ }^{1}$, Edna Dora Martins Newman Luz ${ }^{2}$, \\ Marcos Vinícius Oliveira dos Santos ${ }^{2}$, Francisca Samara Assunção Araújo ${ }^{1}$, Igor Martins Cordeiro ${ }^{3}$
}

\begin{abstract}
${ }^{1}$ Laboratório de Fitopatologia da Embrapa Agroindústria Tropical, Fortaleza/CE; ${ }^{2} \mathrm{SEFIT/CEPEC/CEPLAC,} \mathrm{Ilhéus/BA;}{ }^{3} \mathrm{UFC}$, Fortaleza/CE. Autor para correspondência: Marlon Vagner Valentim Martins (marlon.valentim@embrapa.br) Data de chegada: 01/09/2014. Aceito para publicação em: 30/10/2014.
\end{abstract}

$10.1590 / 0100-5405 / 2027$

A Serra da Ibiapaba, no Estado do Ceará, tem se destacado na produção de flores, sendo essa atividade uma importante oportunidade na geração de renda para as famílias envolvidas. Plantas de lírio doente, da espécie Lilium speciosum Thunb., variedade Constanta, foram enviadas ao Laboratório de Fitopatologia da Embrapa Agroindústria Tropical, Fortaleza-CE, apresentando murcha, amarelecimento das folhas, necrose em bulbo e lesão encharcada acima do colo das plantas. Amostras de tecidos doentes do caule das plantas foram utilizadas para identificar o agente causal através de isolamento em meio de cultura ágar-ágar (AA). As placas de petri foram incubadas em temperatura de $28 \pm 1{ }^{\circ} \mathrm{C}$ por três dias para o crescimento do fitopatógeno. Após esse período, a cultura axênica foi transferida para o meio cenoura-ágar (CA) para a caracterização morfológica realizada no Phytolab, do Centro de Pesquisas do Cacau/Ceplac, Ilhéus-BA. O agente causal apresentou crescimento micelial branco e esporângios predominantemente não caducos, papilados, com forma variando de ovoide a alongado ou elipsoide, com média de comprimento $41,9 \pm 0,9 \mu \mathrm{m}$ e de largura $32,6 \pm 0,7 \mu \mathrm{m}$, com relação comprimento/largura de 1,3:1 (média de 50 esporângios avaliados em caldo de cenoura), com abertura do poro apical das papilas medindo $6,6 \pm 0,2 \mu \mathrm{m}$ (Figura 1A); clamidósporos terminais e intercalares presentes e formados isoladamente com 23,7 $\pm 0,9 \mu \mathrm{m}$ de diâmetro (Figura 1B). Oósporos não foram observados em cultura tanto em CA quanto em caldo de cenoura. $\mathrm{O}$ isolado formou culturas petaloides em cenoura-ágar e cresceu a $35^{\circ} \mathrm{C}$, embora com redução de crescimento em relação as colônias cultivadas em $24 \pm 1^{\circ} \mathrm{C}$ variando entre 18 e $24 \%$ em 10 placas com meio CA. Pelas características apresentadas, trata-se da espécie Phytophthora nicotianae Breda de Hann (sin. Phytophthora parasitica Dastur). Esta espécie tem sido relatada na Hungria causando doença em lírio nas cv. London e Stargazer (Bakonyi, J. et al. Plant Pathology 50: 795. 2001). No Brasil, P. parasitica foi constatada em lírio da paz (Spathiphyllum wallisi Regel) (Fischer, I.H. et al. Fitopatologia Brasileira 29: 690. 2004). Para a confirmação do agente causal, foi realizado o postulado de Koch com inoculação de P. nicotianae em plantas adultas (sem florescimento) sadias de lírio. A inoculação foi realizada através de um corte em bisel no caule das plantas para introdução de discos, com $6,5 \mathrm{~mm}$ de diâmetro, de meio de cultura contendo estruturas do fitopatógeno. Nos pontos inoculados foram colocados algodão estéril umedecido com água autoclavada e selados com Parafilm ${ }^{\circledR}$. As plantas inoculadas foram incubadas em casa-de-vegetação em temperatura ambiente $\left(28 \pm 3^{\circ} \mathrm{C}\right)$ com sistema de nebulização até o surgimento dos primeiros sintomas. Após três dias de incubação, as plantas inoculadas apresentaram sintomas de amarelecimento e necrose no ponto de inoculação. Por outro lado, as plantas testemunhas apenas inoculadas com meio de cultura sem o crescimento do oomiceto não apresentaram os sintomas característicos da doença (Figuras 1C e 1D). Amostras das plantas doentes foram então utilizadas para isolamento em meio AA, tendo sido confirmada a presença do patógeno. Esse é o primeiro relato de P. nicotianae em L. speciosum no Brasil.
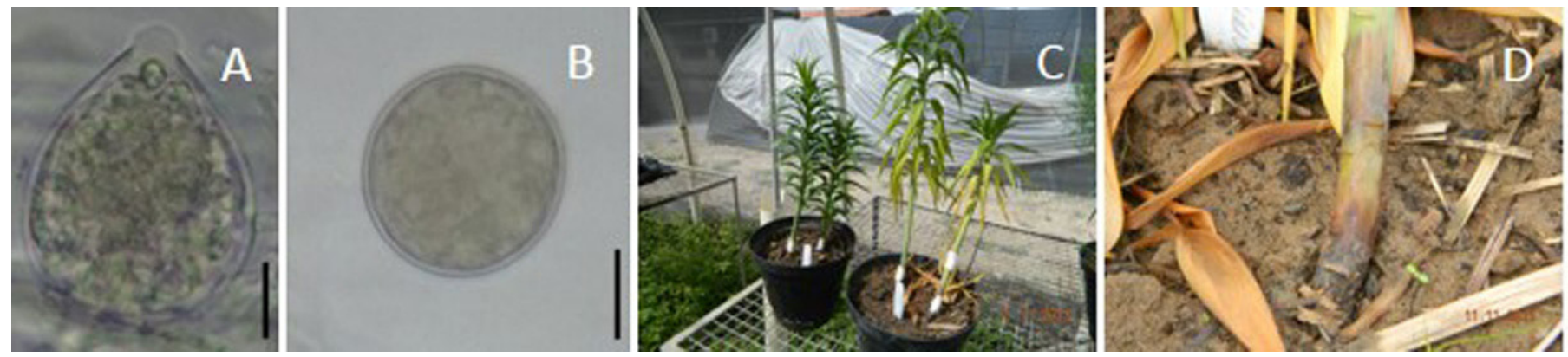

Figura 1. Esporângio (A); clamidósporo (B); plantas de lírio sem (à esquerda) e com (à direita) sintoma de amarelecimento (C); e necrose causada pela infecção de P. nicotianae (D). Barras $=10 \mu \mathrm{m}$. 